INEEL/EXT-99-01163

January 2000

\title{
Silicon-Polymer Encapsulation of High-Level Calcine Waste for Transportation or Disposal
}
G. G. Loomis
C. M. Miller
J. A. Giansiracusa
R. Kimmel
S. V. Prewett 


\title{
Silicon-Polymer Encapsulation of High-Level Calcine Waste for Transportation or Disposal
}

\author{
G. G. Loomis \\ C. M. Miller \\ J. A. Giansiracusa \\ R. Kimmel \\ Stephen V. Prewett \\ Published January 2000
}

Idaho National Engineering and Environmental Laboratory Idaho Falls, Idaho 83415

Prepared for the

U.S. Department of Energy

Assistant Secretary for Environmental Management

Under DOE Idaho Operations Office

Contract DE-AC07-99ID13727 


\begin{abstract}
This report presents the results of an experimental study investigating the potential uses for silicon-polymer encapsulation of High Level Calcine Waste currently stored within the Idaho Nuclear Technology and Engineering Center (INTEC) at the Idaho National Engineering and Environmental Laboratory (INEEL). The study investigated two different applications of silicon polymer encapsulation. One application is using silicon polymer to produce a waste form suitable for disposal at a High Level Radioactive Waste Disposal Facility directly and the other application is encapsulation of the calcine material for transportation to an offsite melter for further processing. A simulated waste material from INTEC called pilot scale calcine which contained hazardous materials but no radioactive isotopes was used for the study which was performed at the University of Akron under special arrangement with Orbit Technologies the originators of the silicon polymer process called Polymer Encapsulation Technology (PET).

This document first discusses the PET process, followed by a presentation of past studies involving PET applications to waste problems. Next, the results of an experimental study are presented on encapsulation of the INTEC calcine waste as it applies to transportation or disposal of calcine waste. Results relating to long-term disposal include: 1) a characterization of the pilot calcine waste, 2) Toxicity Characteristic Leaching Procedure (TCLP) testing of an optimum mixture of pilot calcine, polysiloxane and special additives, and, 3) Material Characterization Center testing MCC-1P evaluation of the optimum waste form. Results relating to transportation of the calcine material for a mixture of maximum waste loading include: compressive strength testing, 10-m drop test, melt testing and a Department of Transportation (DOT) Oxidizer test.
\end{abstract}




\section{SUMMARY}

At the Idaho National Engineering and Environmental Laboratory (INEEL), the Department of Energy reprocessed spent nuclear fuel at the Idaho Chemical Processing Plant (now called the Idaho Nuclear Technology and Engineering Center (INTEC)). The reprocessing resulted in a liquid solution considered high-level waste that was then treated in a process that resulted in a dry granular powder called Calcined waste. This material is not only a mixed waste with heavy metals, it is also highly radioactive and is presently stored in steel bins. The Department of Energy is currently considering the final disposition of this material and the plans include melting the material into a glass waste form for shipment to a Federal permanent disposal site. The Department of Energy is interested in alternatives to building a glass melter in Idaho and have proposed that the waste could be temporarily stabilized for shipment to an offsite melter potentially at Hanford. Another alternative is to apply a non-thermal encapsulation process directly to the calcine waste in Idaho. This process must satisfy waste shipping and acceptance criteria at the proposed disposal site. Silicon-polymer encapsulation is a potential candidate technology that applies to both of these alternatives.

This report presents the results of an experimental study investigating the potential uses for silicon-polymer encapsulation of High Level Calcine Waste currently stored within the INTEC. The study investigated two different applications of the silicon-polymer process called Polymer Encapsulation Technology (PET) offered by Orbit Technologies. One application is using PET to produce a waste form suitable for disposal at a High Level radioactive waste disposal facility directly and the other application is encapsulation of the calcine material for transportation to an offsite melter for further processing. The concept of first encapsulating the dry granular calcine material into a cohesively bound material for shipment to an offsite melter is an innovative idea that has the potential to save the Department of Energy the cost of a separate melter (thermal

processor) at the INEEL. As an offshoot of this idea, the experimental study also examined the proof of concept of using the encapsulation process to provide a waste form suitable for shipment in approved casks directly to the high level repository when it is approved.

The experimental study showed a positive proof of concept for both applications of the PET process. In this study, samples of pilot calcine material from the INEEL (hazardous but not radioactive) were used as a surrogate material. This material was shipped to the University of Akron for testing using the Orbit encapsulation technology.

\section{Disposal Option}

A mixture of $40 \mathrm{wt} \%$ calcine and $60 \mathrm{wt} \%$ of Orbit Technologies PET-991 , with proprietary heavy metal scavenger "JJ2", resulted in a waste form that could be considered possible for disposal. During Toxicity Characteristic Leaching Procedure (TCLP) testing the Universal Treatment Standard was met for both cadmium and chromium. Further evidence of a positive proof-of concept is that the Materials Characterization Center (MCC-1P) test on this waste form (at $40 \mathrm{wt} \%$ pilot calcine loading) showed relatively low concentrations of 
contaminants in the leadchate. The Total Mass Loss Rate (TMLR) for all three leachants was less than four $\mathrm{g} / \mathrm{m} 2$-day, with normalized elemental loss rates varying from 0 to $27.8 \mathrm{~g} / \mathrm{m} 2$-day. Leachant characteristic impacts the leaching rate and is metal specific. These numbers compare to values for glass in the "less than $1 \mathrm{~g} / \mathrm{m} 2$-day. Because of the limited budget in this proof of concept study, a full parametric evaluation of waste loading versus leaching for the MCC-1P testing was not performed but is recommended. Even though these initial results do not meet those found in the glass waste form, the initial results suggest a relatively rugged waste form most likely technically adequate for disposal.

\section{Transportation Option}

The concept of using Orbit's PET process to encapsulate Calcine waste prior to shipment to an offsite melter has shown a positive proof-of-concept. A cohesive monolith suitable for drop testing was formulated at $80 \mathrm{wt} \%$ pilot calcine material with the PET-99-2 material provided by Orbit. The compressive strength of the resultant waste form was above 640psi and the sample did not burn for 20 minutes in a Department of Transportation Oxidizer test. Most importantly, during the 10-m drop test on both a concrete floor and steel plate, the monolith was essentially unaffected by the drop, rather it simply elastically bounced. When coupled with an approved stainless steel container virtually no spread of contamination would be expected in a transportation accident. In addition, the material was found to melt at $1000^{\circ} \mathrm{C}$ meaning it could be reduced to molten form at an offsite melter without chemical dissolution.

In summary, the concept of using Orbit and PET to encapsulate calcine waste for both disposal at a permanent High-Level waste repository and for transportation to an offsite melter has shown a positive proof of concept.

It is recommended that more complete testing and evaluation be conducted of Orbit's PET involving:

1. A pilot scale demonstration to include extrudion into actual shipping containers to determine engineering process parameters for this technology (including drop and flame tests on actual shipping containers, possibly DOT-7A drums).

2. Optimization and mixing studies to investigate passing TCLP and other standard requirements at increased waste loading factors, e.g., up to $80 \%$ waste loading.

3. Evaluating compatibility of the PET waste form with an off-site melter.

4. Cost-benefit analysis to evaluate the efficacy of the disposal and transportation applications of PET to high-level calcine waste and as a comparison to other base or candidate technologies. 


\section{CONTENTS}

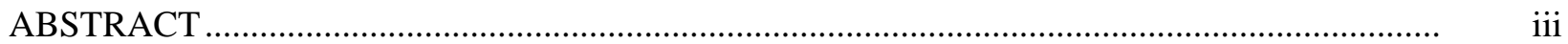

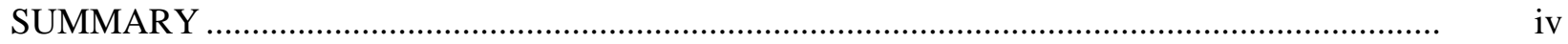

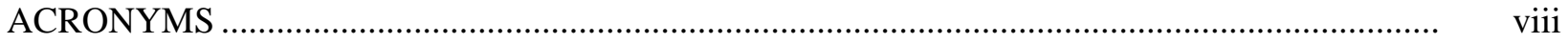

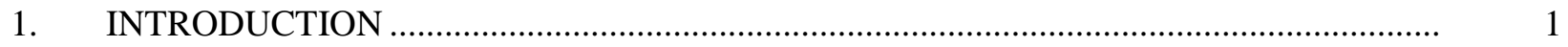

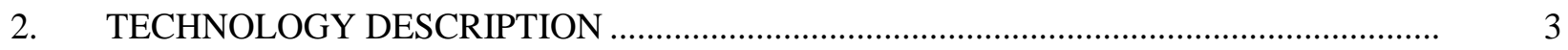

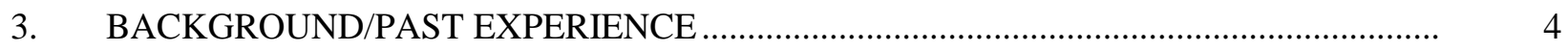

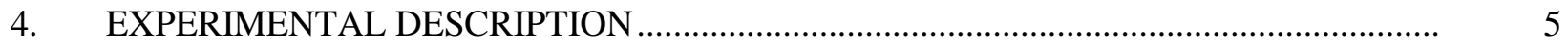

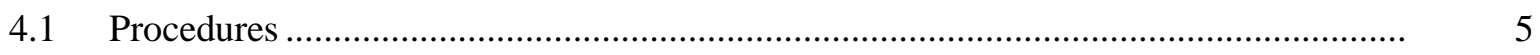

4.1.1 Procedures Specific to Examining the Polymer Encapsulation Technology for the Disposal of Calcine Waste .................................................................... 5

4.1.2 Procedures Associated with the Transportation of the Calcine to an

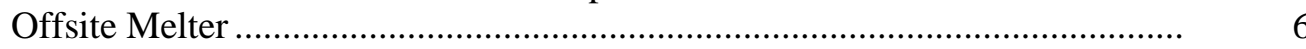

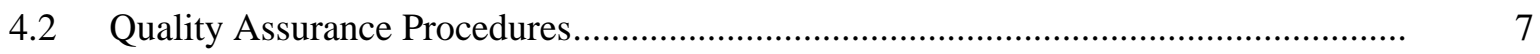

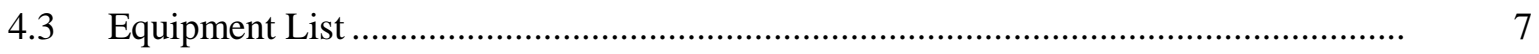

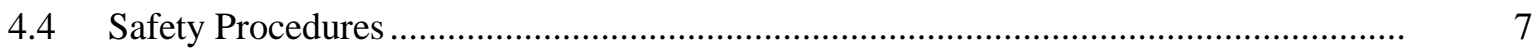

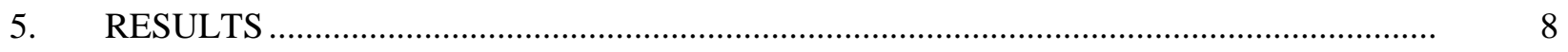

5.1 Pilot Calcine Waste Characterization as a Baseline for Waste Concentrations ............ $\quad 8$

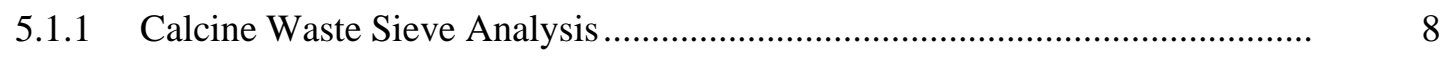

5.1.2 Calcine Waste Metal Analysis ...................................................................... 8

5.2 Studies Supporting Long-Term Disposal Options............................................... 9

5.2.1 Mixing Study to Obtain a Formulation that passes TCLP for Applications in Long-Term Disposal ........................................................... $\quad 10$

5.2.2 MCC-1P Static Leach Test ........................................................................... 11

5.3 Studies Supporting the Transportation of Calcine to an Offsite Melter ......................... 12

5.3.1 Determination of Maximum Waste Loading-Compressive Strength

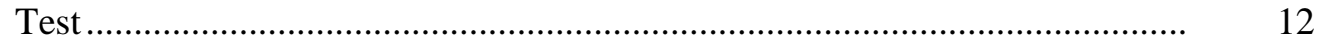

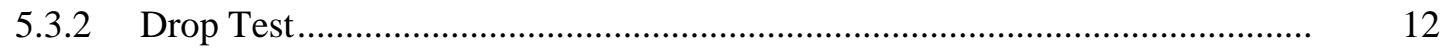

5.3.3 DOT Oxidizer Test............................................................................. 14

5.3.4 Melting Test - Thermal Gravimetric Analysis (TGA) ................................ 14

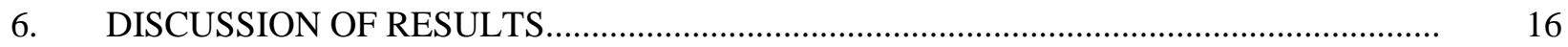




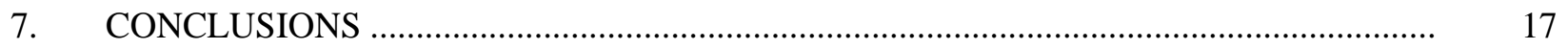

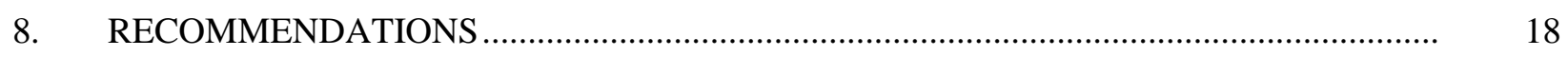

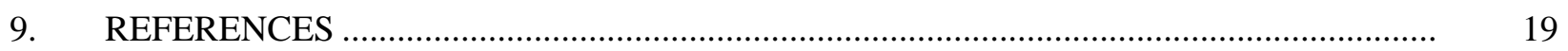

Appendix A-Studying of Influence of Inner Alpha-Radiation and Gamma-Radiation on CSFR

Appendix B-Mixed Waste Salt Encapsulation Using Polysiloxane-Final Report

Appendix C-Polysiloxane Encapsulation of the Low-Level Fraction of Calcined Mixed Waste at INTEC

FIGURES

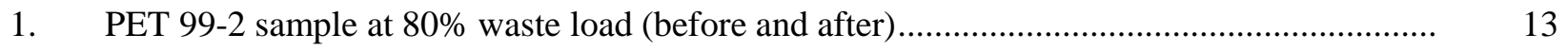

2. Thermal gravimetric analysis (TGA) of 80\% waste load PET 99-2 sample.......................... 14

3. $\quad$ PET 99-2 sample at $80 \%$ waste load (a) before and (b) after TGA test $\left(1000^{\circ} \mathrm{C}\right) \ldots \ldots \ldots \ldots \ldots \ldots \ldots \ldots$

\section{TABLES}

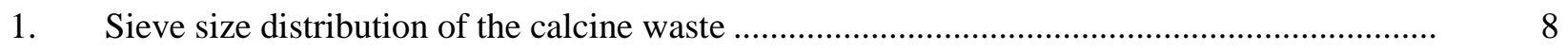

2. Chemical composition of non-radioactive simulated calcine waste determined

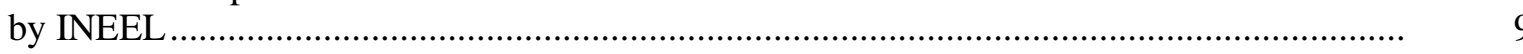

3. Calcine waste acid digestible metal concentration determined by the University

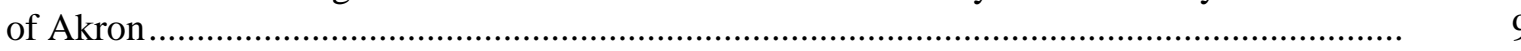

4. Cadmium and chromium TCLP with PET 99-1 without pre-treatment.................................. 10

5. Cadmium and chromium TCLP with JJC1 pretreated waste in PET 99-1 ............................. 10

6. Effect of aqueous pretreatment on TCLP using PET 99-1 ............................................. 11

7. Cadmium and Chromium TCLP as a function of JJC2 addition with PET1 at $40 \%$ waste load

8. 28 day total mass loss rate (TMLR) and normalized elemental leach rates as a function of leachant

9. Compressive strength for base formulations 


\section{ACRONYMS}

\begin{tabular}{ll} 
CSF & ceramic silicon foam \\
DOE & Department of Energy \\
DOT & Department of Transportation \\
ICP & inductively coupled plasma \\
ICP-IES & inductively coupled plasma atomic emission spectrometer \\
INEEL & Idaho National Engineering and Environmental Laboratory \\
INTEC & Idaho Nuclear Technology and Engineering Center \\
MCC-1P & Materials Characterization Center \\
MPC & multipurpose canister \\
NRC & Nuclear Regulatory Commission \\
PET & Polymer Encapsulation Technology \\
SOP & Standard Operating Procedure \\
TCLP & Toxicity Characteristic Leaching Procedure \\
TGA & Thermal Gravimetric Analysis \\
TGA & Thermal Gravimetric Analyzer \\
TMLR & Total Mass Loss Rate \\
UTS & Universal Treatment Standard \\
WASRD & Waste Acceptance System Requirements Document \\
\hline
\end{tabular}




\section{Silicon-Polymer Encapsulation of High-Level Calcine Waste for Transportation or Disposal}

\section{INTRODUCTION}

At the Idaho National Engineering and Environmental Laboratory (INEEL), the Department of Energy reprocessed spent nuclear fuel at the Idaho Chemical Processing Plant (now called the Idaho Nuclear Technology and Engineering Center (INTEC)). The reprocessing resulted in a liquid solution considered high-level waste that was then treated in a process that resulted in a dry granular powder called Calcined waste. This material is not only a mixed waste with heavy metals, it is also highly radioactive and is presently stored in steel bins. The Department of Energy is currently considering the final disposition of this material and the plans include melting the material into a glass waste form for shipment to a Federal permanent disposal site. The Department of Energy is interested in alternatives to building a glass melter in Idaho and have proposed that the waste could be temporarily stabilized for shipment to an off-site melter potentially at Hanford. Another option is to use a non-thermal encapsulation process for the calcine material that could satisfy waste shipping and acceptance criteria at the proposed disposal site. Silicon-polymer encapsulation is a potential candidate technology that could achieve both of these goals. This report presents the results of an experimental study investigating these options using Orbit Technologies Polymer Encapsulation Technology (PET).

Examination of past work on high level waste shows that the waste form is assumed to be a glass material and therefore all the applicable and relevant requirements are applied to the glass paradigm. Therefore, as part of this experimental study, testing normally associated with the glass waste forms were also applied to Orbit's PET systems for both applications (shipping the waste to either an off-site melter or a disposal site).

From a waste acceptance criteria standpoint, the processed waste must meet all requirements as issued in Waste Acceptance System Requirements Document (WASRD) REV-2 May 1996 issued by the DOE office of Civilian Radioactive Waste Management. For waste acceptance at a high level waste repository the waste must be contained in a multipurpose canister (MPC) made of austinitic stainless steel with concentric necks and lifting flanges. These MPC's are used for shipping and disposal but are shipped to the disposal site in specially designed shipping casks with appropriate shielding materials. There has been considerable drop testing and canister design for the MPC's and it is assumed that the silicon-polymer/calcine mixture would be poured directly into these already developed containers.

Specific disposal (repository) requirements are that the waste must:

1. Be a in solid form and placed in sealed containers

2. Be consolidated to limit the availability and generation of particulates

3. Be noncombustible

4. Have no free liquids

5. Not be explosive, pyrophoric, or chemically reactive.

These acceptance criteria will be examined by evaluating the experimental study. 
This document first discusses Orbit's proprietary PET, followed by a discussion of past studies involving silicon-polymer applications to waste problems. Next, the results of an experimental study are presented on encapsulation of the INTEC calcine waste as it applies to transportation or disposal of calcine waste. Finally, there is a section examining the proof of concept of applying this technology to the INTEC calcine waste. 


\section{TECHNOLOGY DESCRIPTION}

The silicon-polymer system is a simple room temperature mixing process in which the base fluid polysiloxane material along with proprietary additives are blended with dry granular waste materials. This mixture is extruded into waste containers while a platinum catalyst is added to start a silicon polymerization process. Polysiloxane is an inorganic thermosetting polymer containing about $50 \%$ vinylpolydimethyl-siloxane, $20 \%$ quartz, $25 \%$ proprietary ingredients and $<5 \%$ water.

The Orbit product used in this study is PET. Generally, PET is formed with a three-part system comprised of the $\mathrm{SiH}$ cross-linker (binder), $\mathrm{SiOH}$, the polysiloxane monomer, and a catalyst. A flame resistant chemical agent is commonly used as the catalyst. Varying the amount of catalyst can vary cure times from a minute upward to hours. The PET systems are at low temperatures (essentially room temperature) and thus requires minimal off-gas systems, contains no volatile metals like mercury and generates no secondary waste

Upon room temperature reaction of the base materials a Si-O-Si bond is formed and hydrogen gas is released. When these silicon atoms are further bonded with organic radicals the resulting material combines the elasticity of organic compounds with the chemical resistance of silicone materials. This sturdy formation allows the silicone molecule to be resistant to extreme temperatures, pressures and chemical environments. Specifically PET can resist contact with acids, alkalis, and attack from oxygen. In fact one study showed that after one-month exposure to $0.1 \mathrm{M}$ nitric acid solutions, the PET exhibited no structural changes.

Common production scale systems will involve simple mixing apparatus similar to that for the cement based waste stabilization systems. The PET base material is relatively expensive due to the base cost of the chemical compounds. However, high waste loadings and low operating costs can counterbalance this expense.

Orbit's PET was first proposed for use at the Chernobyl plant because of its excellent radiation resistance. Studies (ref 1) show that under gamma irradiation, the compressive strength actually increases as the product changes to a more ceramic form.

Any properly sized solid or sludge mixed waste material is a potential candidate for this technology. In particular the secondary salt wastes generated from the treatment of acid gases from thermal units. It is also compatible with other wastes such as incinerator fly and bottom ashes, failed concrete waste forms and soils. The technology has the potential to be extended to other DOE waste streams specifically, stored and retrieved buried TRU waste debris. This includes the sized, solid material such as that sent from the Rocky Flats Plant to the INEEL. 


\section{BACKGROUND/PAST EXPERIENCE}

In 1994, Orbit proposed mixing a polysiloxane material then called ceramic silicon foam (CSF) with inert filler elements to fill and provide structural support to the compartments and voids in the disabled Chernobyl reactor. A variety of material durability testing was performed at the Kurchatov Nuclear Institute-ref 1 (see appendix A) including microstructure analysis, radionuclide sorption, behavior in corrosive mediums, and temperature and pressure effects. As part of that proposal, the radiation effects from gamma and alpha irradiation have been demonstrated at e8R without mechanical breakdown. Testing and analysis showed Orbit's polymer to be very resistant to both gamma and alpha radiation. Early formulations of Orbit's polymer were exposed to $7.5 \mathrm{Grad}$, with later specimens irradiated up to $33 \mathrm{Grad}$ of gamma that showed very little degradation. In addition, alpha activity of 7.7 e+07 Bq placed in a cavity in an Orbit specimen did not diffuse through the matrix of the specimen over a three-month period. Testing was further carried out by the Kurchatov Institute to simulate the harsh conditions the material would encounter during stabilization of Chernobyl reactor debris. Testing was done in very acidic, high radiation and high temperature conditions, which exceeded what would be expected with the INTEC calcine waste. These tests all showed very desirable long-term properties for application for high-level waste type materials including the presence of gamma and alpha emitting radionuclides.

INEEL studied silicon-polymer encapsulation of Pad-A salt which has plutonium/americium in the $\mathrm{pCi} / \mathrm{g}$ range and chromium +6 in the 180ppm range. During this FY1997 study-ref 2 and 3 (see Appendix B), a pad-A surrogate was formulated without the radioactive component. The surrogate had chromium +6 at $1045 \mathrm{ppm}$ which was 5.8 times the actual waste and at $30 \%$ waste loadings, the waste form passed the 1997 TCLP limit (2.4ppm in the leachate with a allowable of 5ppm). Considering that the source term was a factor of 5.8 too high in the surrogate, at $30 \%$ waste loading, the waste form would most probably pass the new limit of $0.86 \mathrm{ppm}$ as well. An additional Mixed Waste Focus Area surrogate was also tested and at both 30 and $50 \mathrm{wt} \%$ surrogate, the new limit for chromium, cadmium, mercury and lead also passed. This surrogate had as a source term $1000 \mathrm{mg} / \mathrm{kg}$ of the compounds $\mathrm{PbO}, \mathrm{CrO} 3, \mathrm{HgO}, \mathrm{CdO}$ and $\mathrm{NiO}$. The study also ran some 30 day water and base immersion tests with negligible change in compressive strength with $50 \mathrm{wt} \%$ waste loading for the pad-A surrogate mixed with polysiloxane.

INEEL also examined encapsulation of a proposed low level calcined material that would result from moving the calcine waste through the TRUEX process and then resin columns for Cs removal in a FY-98 study-ref 4 (see Appendix C). The surrogate material was made according to formulas provided by INTEC which resulted in a dry surrogate with $4500 \mathrm{mg} / \mathrm{kg} \mathrm{Cd}, 7800 \mathrm{mg} / \mathrm{kg} \mathrm{Cr}, 2440 \mathrm{mg} / \mathrm{kg}$ lead, 1960 $\mathrm{mg} / \mathrm{kg} \mathrm{Hg}$. Even at $48 \mathrm{wt} \%$ waste loading, the compressive strength was $550 \mathrm{psi}$. With proprietary scavengers, at $38 \mathrm{wt} \%$ waste loading, TCLP leachate results were: Cadmium $3.5 \mathrm{ppm}$, Chromium 3.5 $\mathrm{ppm}$, lead $2.2 \mathrm{ppm}$ and mercury $0.002 \mathrm{ppm}$ compared to most restrictive treatment standard of $0.11 \mathrm{ppm}$ for cadmium, $0.86 \mathrm{ppm}$ for chromium, $0.37 \mathrm{ppm}$ for lead, and $0.025 \mathrm{ppm}$ for mercury. Therefore, only mercury passed the most restrictive standard; however, it was recognized that more work on the scavenger could lead to better results. 


\section{EXPERIMENTAL DESCRIPTION}

The Orbit PET material and the calcine surrogate (created at the INEEL INTEC during pilot scale operations) were combined in a mixing study and evaluated with several standard waste form acceptance tests. The objective of this study was to evaluate the mixture of polysiloxane and calcine waste for both disposal at a final high level repository and for the potential transportation of the encapsulated calcine material to an offsite melter for processing.

\subsection{Procedures}

The pilot calcine material was shipped from INEEL to the University of Akron and was first sieved using standard mesh screens at 16, 30, 40, 60, 100, 120, and 200 mesh to determine the size distribution of the material. Next, the total metals evaluation was performed on the mixture to determine the heavy metal concentration using Inductively Coupled Mass Spectrometry.

\subsubsection{Procedures Specific to Examining the Polymer Encapsulation Technology for the Disposal of Calcine Waste}

\subsubsection{Mixing Study to Determine a Waste Loading/Scavenger Combination to Pass} Toxicity Characteristic Leaching Procedure (TCLP) Testing. Using the surrogate material and PET, a parametric mixing study was first performed. In this mixing study, a variety of surrogate waste material, polysiloxane, proprietary fillers, and proprietary metal scavengers were combined to make waste forms that where subjected to the Toxicity Characteristic Leach Procedure. This study was a parametric in that various mixtures were attempted and then subjected to TCLP until TCLP was passed for the contaminants of concern. Depending on the selected waste loading, the appropriate weight of polysiloxane, waste, and catalyst was measured using an Ohaus Analytical Scale. Prior to mixing, the catalyst was stored in a plastic syringe and the polysiloxane and waste were stored in plastic molds (3" diameter by 6" tall and 2" diameter by 4" tall cylinders). Mixing took place in glass beakers using a hand-held drill with a stainless steel mixing paddle (the drill remained on during the entire mixing process. The order of addition was polysiloxane, calcine waste, and catalyst. Curing time for all the samples was maintained at a minimum of 48 hours. The samples were then subjected to standard TCLP procedures as follows: A simulated TCLP procedure was adopted from that set forth by the United States Environmental Protection Agency. Cured silicone foam samples were cut into $5 \mathrm{~mm}$ cubes which would pass through a $9.432 \mathrm{~mm}$ sieve and be retained on a $4.76 \mathrm{~mm}$ sieve. A $250 \mathrm{ml}$ HDPE bottle was used with 10 grams of sample cubes and $200 \mathrm{ml}$ of dilute glacial acetic acid extraction fluid at $\mathrm{pH}$ less than 3.00. The bottles were placed on a Burrell Wrist Action Shaker set at one (on a scale of 0 to 10) for 18 hours. After this period the contents were passed through a $0.7 \mu \mathrm{m}$ borosilicate glass filter, acid washed with approximately $50 \mathrm{ml}$ of $1 \mathrm{~N}$ nitric acid and $150 \mathrm{ml}$ of deionized (DI) water. A $10 \mathrm{ml}$ volume of each filtered solution was then stored in $10 \mathrm{ml}$ HDPE bottles to which $55 \mu \mathrm{l}$ of $15.8 \mathrm{~N}$ nitric acid was added for preservation. Metals were analyzed with the use of a Perkin Elmer inductively coupled plasma atomic emission spectrometer (ICP-AES). The sample with the highest waste loading that passes the Universal Treatment Standards (UTS) was used for the following tests.

4.1.1.2 Durability Testing (MCC-1P) on the Optimum Waste Form. Heavy metal leaching from the waste form was evaluated using the MCC-1P Static Leach Test. This test method is the basis for an initial ranking of the leach resistance of waste forms. Only that waste loading that passed the TCLP for the UTS were used. Three specimens of known volume and geometric surface area ( 1"x1" cylinders) were immersed in the reference leachates (total samples $=9$ ) without agitation for 28 days period at defined temperature $\left(90^{\circ} \mathrm{C}\right)$. The SA/Volume was held constant within 0.0005 to $0.0100 \mathrm{~mm}^{-1}$. Three reference leachates were used: pure water, silicate/ bicarbonate, and brine. The leach 
containers had a diameter to height ratio between 0.5 and 2.0. The container shall be sufficiently tight and impervious to limit the leachate loss during the test to less than $10 \%$ of the original volume. After the determination of $\mathrm{pH}$ and volume of the leachate to be used, the volume of the leachate was placed into a clean leach container. Specimens were completely submerged into the leachate and the container was placed into the environmental chamber preheated to the test temperature of $90^{\circ} \mathrm{C}$. After the test period of 28 days the leachate was measured for mass loss of any particular element (cadmium and chromium) and normalized elemental mass loss was calculated.

\subsubsection{Procedures Associated with the Transportation of the Calcine to an Offsite Melter}

A series of tests were performed on a maximum loading matrix to examine the potential for using the polysiloxane encapsulation process for a pretreatment prior to shipping the calcine to an offsite melter. The tests included a mixing study to determine a maximum loading that could be considered competent to be a standalone monolith and further to pass a drop test without significant aerosolization of the contaminants. The mixing study was performed on a trial and error basis using the same techniques discussed above. The resultant candidate simulated waste form consisting of pilot calcine treated with the PET was subjected to the following tests:

4.1.2.1 Compressive Strength Test (ASTM C-695). A waste form's mechanical integrity and ability to withstand loading pressures in a disposal environment is directly related to compressive strength. Since the PET treated waste forms do not have a discrete brittle fracture yield point under compressive loads, ASTM C-695 "Compressive Properties of Rigid Plastics" was followed. The standard test specimens were right cylinders with a length twice its principal diameter (preferred size is 0.5 inch by 1.0 inch length). A total of five samples were formed, to provide smooth, flat surfaces. The width and thickness of each specimen was recorded for several points along the length. The minimum value of the cross sectional area was calculated and recorded. Each sample was tested with a MTS 300 HV-1005 loading apparatus, equipped with an extensiometer. Loads were recorded with corresponding compressive strain until the yield point was reached (or the specimen fails). The compressive strength was calculated by dividing the maximum compressive load carried by the specimen during the test by the original minimum cross-sectional area of the sample. Compressive strength was reported as the average value \pm one standard deviation.

4.1.2.2 Drop Test. To determine the resultant size distribution of the waste form, a drop test was performed on a using the maximum waste loading. The standard test specimens had a height to diameter ratio of 2:1. The volume of the specimens were such that the force generated during the drop was equivalent to the force developed by dropping a stainless steel cylinder containing the waste from a height of 10.0 meters (at the parking garage at University of Akron). The specimen was dropped on a standard cement bed and stainless steel plate. Throughout the test a camcorder recorded the procedure of the drop test. Still photographs of the specimens were taken before and after the impact. After the test, any shattered specimens were analyzed for size distribution by using standard geological soil sieves.

4.1.2.3 Melting Test. A melting test was performed to evaluate the meltability at an offsite melter of the PET stabilized waste form. Specimens in the form of cylinders 1"x 1" were evaluated in a Thermal Gravimetric Analyzer (TGA). The temperature of the oven was increased until the melting point of the waste form was reached. The temperature at which the waste form melted was measured using a Du Pont Model TGA 2100 Thermal Gravimetric Analyzer.

4.1.2.4 Oxidizer Test. The Department of Transportation (DOT) Oxidizer test was performed to measure the capability of the waste form to increase the burning rate or burning intensity of a combustible solid. The maximum loading waste form was used for this test. The performance of the waste form was 
compared with three reference substances: ammonium persulphate, potassium perchlorate and potassium bromate. The reference substances were dried at $65^{\circ} \mathrm{C}$ for 12 hours and passed a sieve of mesh size less than $0.3 \mathrm{~mm}$. The reference mixtures were prepared by mixing the $15 \mathrm{~g}$ of the reference substance and $15 \mathrm{~g}$ of wood saw dust thoroughly. The waste form was made into two mixtures with the sawdust. For one mixture $15 \mathrm{~g}$ of sawdust and $15 \mathrm{~g}$ of the waste form (1:1 ratio) were mixed together. For the other mixture 24-g of the waste form and $6 \mathrm{~g}$ of sawdust (4:1 ratio) were mixed together. Each of the five mixtures were formed into a conical pile with a base diameter of approximately $35 \mathrm{~mm}$ and a height of $25 \mathrm{~mm}$ on the low heat conducting surface. A wire of inert material was put through the pile spanning the base of the cone, a distance of $1 \mathrm{~mm}$ above the test surface. The voltage was controlled with a variable transformer until the temperature of the wire became $1000^{\circ} \mathrm{C}$ and the process continued until ignition. The time that takes for the cone of mixture to burn, until all the flames have disappeared were noted.

\subsection{Quality Assurance Procedures}

All testing was accomplished according to the test plan and recorded in a logbook. The appropriate controls for individual tests were prepared and measured and data was reported according to the ASTM or with other accepted statistical measures.

\subsection{Equipment List}

The following equipment was used in the testing program:

Water-Nanopure system

Drill with stainless steel mixing blade

pH meter-Cole Parmer Model 05669-20

Inductively coupled plasma (ICP) analyzer

Wrist Action Shaker (TCLP Extraction)

Microscope with digital analysis

Water bath-Fisher Model 127

Drying oven-Grieve Model LW-201C

Scale-Ohaus Analytical

Plastic syringe

Glass and plastic beakers

Vacuum filtration unit

MTS 300 HV-1005 loading apparatus

Geological soil sieves (Standard)

Thermal Gravimetric Analyzer-Du Pont TGA 2100

\subsection{Safety Procedures}

General laboratory procedures were followed, as outlined in the Standard Operating Procedures (SOP) for Research and the University of Akron Safety Manual under the guidance of Christopher M. Miller Ph.D., PE., the principle investigator at the University of Akron. The major hazard for this research included exposure to the calcine surrogate which contained cadmium, lead, and chromium. Therefore, proper protective clothing were worn at all times (e.g. gloves, lab coat, and goggles). In addition, training on the proper handling of these materials was conducted and recorded. The University of Akron has undergone a compliance inspection by the INEEL. 


\section{RESULTS}

Two different Orbit Technologies polymer formulations of polysiloxane were investigated to address two different performance objectives. The commercial formulations are hereafter referred to as PET 99-1 and PET 99-2. PET 99-1 material was used to investigate final waste storage and disposal, whereas PET 99-2 was used to investigate temporary storage and transportation issues. The addition of several heavy metal scavenger additives (hereafter referred to as JJC1, JJC2, and JJC3) as well as several aqueous pretreatment processes was also examined to reduce heavy metal leaching. The results of the study follow:

\subsection{Pilot Calcine Waste Characterization as a Baseline for Waste Concentrations}

\subsubsection{Calcine Waste Sieve Analysis}

Approximately 5 gal. of pilot calcine material was received by the University of Akron which was from the INEEL INTEC cargo container A number 74. In order to determine the sieve size distribution of the waste, a measured quantity of the waste was taken and placed in a series of standard geology sieves placed in order of decreasing size. The sieves were shaken for a period of 30 minutes in the enclosed chamber. After this, the component of the waste retained on every sieve was measured and size distribution was analyzed. Table 1 shows the result of the corresponding size distribution. The majority of the waste $(>95 \%)$ was retained on a sieve \#60 or smaller.

\subsubsection{Calcine Waste Metal Analysis}

A chemical composition of the nominal pilot calcine material was determined at the INEEL and is shown on Table 2. The pilot material consists of multiple metal oxides including some hazardous constituents.

To obtain baseline waste loadings, further evaluation by University of Akron was performed on the shipped pilot calcine using acid digestion of the calcine waste followed by inductively coupled plasma (ICP). Table 3 shows the results of this study indicating large quantities of chromium, cadmium and some lead. These values were used in all subsequent calculations involving calcine metal concentrations (e.g. MCC-1P). The greatest metal concentrations were chromium $(1036 \mathrm{mg} / \mathrm{kg})$ and cadmium $(330 \mathrm{mg} / \mathrm{kg})$. The work presented in this document uses the University of Akron digestible metal analyses shown in Table 3 for leaching calculations.

Table 1. Sieve size distribution of the calcine waste.

\begin{tabular}{cccc}
\hline $\begin{array}{c}\text { Sieve Size } \\
\text { Code }\end{array}$ & $\begin{array}{c}\text { Sieve } \\
\text { Number }\end{array}$ & $\begin{array}{c}\text { Sieve Opening } \\
\text { (inches) }\end{array}$ & $\begin{array}{c}\text { \% Waste } \\
\text { Retained on Sieve }\end{array}$ \\
\hline A & 16 & 0.0460 & 0.74 \\
B & 30 & 0.0234 & 6.15 \\
C & 40 & 0.0165 & 13.61 \\
D & 60 & 0.0098 & 74.96 \\
E & 100 & 0.0058 & 3.98 \\
F & 120 & 0.0034 & 0.06 \\
G & 200 & 0.0029 & 0.08 \\
H & 200 & $<0.0029$ & 0.42 \\
\hline
\end{tabular}


Table 2. Chemical composition of non-radioactive simulated calcine waste determined by INEEL.

\begin{tabular}{lc} 
Component & $\begin{array}{c}\text { Simulated Calcine } \\
(\text { wt } \%)\end{array}$ \\
$\mathrm{Al}_{2} \mathrm{O}_{3}$ & 8.3 \\
$\mathrm{~B}_{2} \mathrm{O}_{3}$ & 4.4 \\
$\mathrm{CaO}$ & 11.5 \\
$\mathrm{CaF}_{2}$ & 35.1 \\
$\mathrm{CdO}$ & 3.9 \\
$\mathrm{CeO}_{2}$ & 1.1 \\
$\mathrm{Cl}^{-1}$ & 0.2 \\
$\mathrm{Cr}_{2} \mathrm{O}_{3}$ & 1.2 \\
$\mathrm{Cs}_{2} \mathrm{O}$ & 0.1 \\
$\mathrm{Fe}_{2} \mathrm{O}_{3}$ & 0.3 \\
$\mathrm{~K}_{2} \mathrm{O}$ & 1.7 \\
$\mathrm{Na}_{2} \mathrm{O}$ & 5.3 \\
$\mathrm{SrO}$ & 0.6 \\
$\mathrm{SeO}$ & 0.2 \\
$\mathrm{ZrO}_{2}$ & 16.9 \\
$\mathrm{PO}_{4}^{-3}$ & 0.2 \\
$\mathrm{Miscellaneous}$ & 9.0 \\
$\mathrm{Total}$ & 100.00 \\
\hline
\end{tabular}

Table 3. Calcine waste acid digestible metal concentration determined by the University of Akron.

\begin{tabular}{cccc} 
Metal & $\begin{array}{c}\text { Concentration } \\
(\mathrm{mg} / \mathrm{kg})\end{array}$ & Metal & $\begin{array}{c}\text { Concentration } \\
(\mathrm{mg} / \mathrm{kg})\end{array}$ \\
\hline $\mathrm{Cd}$ & 330 & $\mathrm{As}$ & $<0.2$ \\
$\mathrm{Cr}$ & 1036 & $\mathrm{Ba}$ & $<20$ \\
$\mathrm{~Pb}$ & 25 & $\mathrm{Se}$ & $<0.4$ \\
\hline
\end{tabular}

for leaching evaluations in testing presented in this document. An explanation for this discrepancy could be that the pilot material is somewhat heterogeneous accounting for the different assays.

\subsection{Studies Supporting Long-Term Disposal Options}

Two basic studies were performed to examine the long-term disposal option. For that option, the waste material would be mixed with the polysiloxane system and placed in appropriate waste containers for shipment directly to a High Level Waste repository. First, a mixing study was performed to determine 
a mixture of polysiloxane and special additives that could pass TCLP for a maximum possible waste loading. Next, the MCC-1P monolith test was performed on the best waste-loading sample.

\subsubsection{Mixing Study to Obtain a Formulation that passes TCLP for Applications in Long-Term Disposal}

Various mixtures of the basic polysiloxane material consisting of PET 99-1 and various additives were formulated and put to the TCLP testing protocol. As a baseline, and based on previous success with nitrate surrogate salts(ref), heavy metal leaching was examined first with an improved Orbit formulation designated as PET 99-1. Cadmium and chromium were selectively monitored because they have the greatest metal concentrations in the calcine waste (see Table 3).

5.2.1.1 Cadmium and Chromium TCLP Leaching from Base Formulations. Table 4 shows the cadmium and chromium leaching in PET 99-1 encapsulated samples with increasing waste load. These represent the base polysiloxane with Orbit fillers but no metal scavengers (pre-treatments). Cadmium and chromium concentrations exceeded the Universal Treatment Standards (UTS) levels. In addition, the data shows an expected increase in the leachate metal concentration with an increase waste load.

5.2.1.2 Effect of JJC1 Pretreatment. Calcine waste was pretreated with JJC1 material (5 wt\%) and water, followed by oven drying at $100^{\circ} \mathrm{C}$, and then encapsulated. Table 5 shows cadmium and chromium TCLP results from these samples, as well as a JJC1 sample with JJC2 addition. Although the metal levels are still greater than the UTS, there was a marked decrease in metal leachate concentration with increasing waste load (41\% reduction for $\mathrm{Cr}$ and $50 \%$ reduction for $\mathrm{Cd}$ for a waste load increase from $40 \%$ to $50 \%$ ). Furthermore, JJC2 addition reduced both cadmium and chromium concentrations at comparable waste load (reduced $\mathrm{Cr}$ leaching by $75 \%$ and $\mathrm{Cd}$ leaching by $73 \%$ ), indicating its potential, which is examined later in this report. Clearly, additives can improve the TCLP results. Based on the success of JJC1 and JJC2 addition, it was determined that aqueous pretreatment of the calcine waste before encapsulation could also provide a means to further reduce leaching of heavy metals.

Table 4. Cadmium and chromium TCLP with PET 99-1 without pre-treatment.

\begin{tabular}{cccc}
\hline Metal & $\begin{array}{c}\text { PET 99-1 } \\
40 \% \text { Load } \\
(\mathrm{mg} / \mathrm{l})\end{array}$ & $\begin{array}{c}\text { PET 99-1 } \\
75 \% \text { Load } \\
(\mathrm{mg} / \mathrm{l})\end{array}$ & $\begin{array}{c}\text { UTS } \\
(\mathrm{mg} / \mathrm{l})\end{array}$ \\
\hline Cadmium & $0.69 \pm 0.01$ & $2.14 \pm 0.02$ & 0.11 \\
Chromium & $2.15 \pm 0.02$ & $7.10 \pm 0.06$ & 0.60 \\
\hline
\end{tabular}

Table 5. Cadmium and chromium TCLP with JJC1 pretreated waste in PET 99-1.

\begin{tabular}{lcccc}
\hline \multicolumn{1}{c}{ Metal } & $\begin{array}{c}\text { JJC1 } \\
\text { 40\% Load } \\
(\mathrm{mg} / \mathrm{l})\end{array}$ & $\begin{array}{c}\text { JJC1 } \\
50 \% \text { Load } \\
(\mathrm{mg} / \mathrm{l})\end{array}$ & $\begin{array}{c}\mathrm{JJC1}^{\mathrm{a}} \\
40 \% \text { Load } \\
(\mathrm{mg} / \mathrm{l})\end{array}$ & $\begin{array}{c}\text { UTS } \\
(\mathrm{mg} / \mathrm{l})\end{array}$ \\
\hline Cadmium & $1.24 \pm 0.01$ & $0.62 \pm 0.004$ & $0.34 \pm 0.01$ & 0.11 \\
Chromium & $4.55 \pm 0.02$ & $2.67 \pm 0.02$ & $1.14 \pm 0.02$ & 0.60 \\
\hline \multicolumn{2}{l}{ a. Sample also contains 5.0\% by weight of JJC2. } \\
\hline
\end{tabular}


5.2.1.3 Effect of Aqueous Pretreatment of the Calcine Waste. Pretreatment of the calcine waste was accomplished by mixing the calcine waste, water, and additives (JJC1, JJC2, and JJC3 at $5 \%$ wt.) and then evaporating the water in an oven at $100^{\circ} \mathrm{C}$. Table 6 shows the leaching results after aqueous pretreatment before encapsulation. Results indicate that aqueous pretreatment of the JJC1-treated waste reduced the leaching of cadmium (by as much as 70\%) from the samples. Aqueous pretreatment, however, did not significantly reduce leaching compared to direct material addition to the PET system.

5.2.1.4 Effect of JJC2 Addition. TCLP results as a function of JJC2 addition for cadmium and chromium are shown in Table 7. JJC2 reduced the leaching of cadmium and chromium, with a 77\% reduction in cadmium leaching and $71 \%$ reduction in chromium leaching at 5\% addition. More importantly, the final TCLP values are less than the UTS levels for both cadmium and chromium. These results also imply that by increasing the proportion of JJC2 beyond $5 \%$ it might be possible to reduce the cadmium and chromium leachate concentrations further and thus perhaps allow higher waste loadings. Increasing the mass of JJC2 beyond 5\%, however, poisoned the catalyst and prohibited sample curing.

\subsubsection{MCC-1P Static Leach Test}

This test forms a basis for examining the chemical durability of waste forms. Matrix B of the testing protocol was selected for this test (reference leachants: brine, silicate and de-ionized water). Samples containing 40\% waste and 5\% JCC2 (note: this combination achieved the lowest TCLP values) of known volume and surface area were immersed without agitation for a period of 28 days in a closed environmental chamber at a fixed temperature of $90^{\circ} \mathrm{C}$. The 28 day Total Mass Loss Rate (TMLR) and

Table 6. Effect of aqueous pretreatment on TCLP using PET 99-1.

\begin{tabular}{|c|c|c|c|c|c|}
\hline Metal & $\begin{array}{c}\text { Calcine }^{\mathrm{a}} \\
40 \% \text { Load } \\
(\mathrm{mg} / \mathrm{l})\end{array}$ & $\begin{array}{c}\mathrm{JJC1}^{\mathrm{a}} \\
40 \% \text { Load } \\
(\mathrm{mg} / \mathrm{l})\end{array}$ & $\begin{array}{c}\text { Calcine }^{\mathrm{b}} \\
40 \% \text { Load } \\
(\mathrm{mg} / \mathrm{l})\end{array}$ & $\begin{array}{c}\mathrm{JJC1}^{\mathrm{b}} \\
40 \% \text { Load } \\
(\mathrm{mg} / \mathrm{l}) \\
\end{array}$ & $\begin{array}{c}\text { UTS } \\
(\mathrm{mg} / \mathrm{l}) \\
\end{array}$ \\
\hline Cadmium & $0.89 \pm 0.01$ & $0.81 \pm 0.01$ & $0.99 \pm 0.01$ & $0.24 \pm 0.004$ & 0.11 \\
\hline Chromium & $2.89 \pm 0.03$ & $2.80 \pm 0.03$ & $2.41 \pm 0.02$ & $1.83 \pm 0.01$ & 0.60 \\
\hline
\end{tabular}

Table 7. Cadmium and Chromium TCLP as a function of JJC2 addition with PET1 at $40 \%$ waste load.

\begin{tabular}{lccc}
\hline $\begin{array}{c}\text { JJC2 } \\
(\mathrm{wt} \%)\end{array}$ & $\begin{array}{c}\text { Cadmium }^{\mathrm{a}} \\
(\mathrm{mg} / \mathrm{l})\end{array}$ & $\begin{array}{c}\text { Chromium }^{\mathrm{b}} \\
(\mathrm{mg} / \mathrm{l})\end{array}$ \\
\hline 0.0 & 0.69 & 2.15 \\
& 0.8 & 0.78 & 2.44 \\
& 1.6 & 0.51 & 1.69 \\
& 5.0 & 0.10 & 0.58 \\
\hline a. UTS $=0.11 \mathrm{mg} / \mathrm{l}$ & & & \\
b. UTS $=0.60 \mathrm{mg} / \mathrm{l}$ & & & \\
\hline
\end{tabular}


Normalized Elemental Loss Rates for cadmium and chromium as a function of leachant condition are shown in Table 8 . The TMLR for all three leachants was less than four $\mathrm{g} / \mathrm{m} 2$-day, with normalized elemental loss rates varying from 0 to $27.8 \mathrm{~g} / \mathrm{m} 2$-day. Leachant characteristic impacts the leaching rate and is metal specific. These numbers compare to values for glass in the "less than $1 \mathrm{~g} / \mathrm{m} 2$-day as stated in reference 5 .

Table 8. 28 day total mass loss rate (TMLR) and normalized elemental leach rates as a function of leachant.

\begin{tabular}{lccc}
\hline \multicolumn{1}{c}{ Leachant } & $\begin{array}{c}\text { TMLR } \\
\left(\mathrm{g} / \mathrm{m}^{2} \text {-day }\right)\end{array}$ & $\begin{array}{c}\mathrm{Cd} \\
\left(\mathrm{g} / \mathrm{m}^{2} \text {-day }\right)\end{array}$ & $\begin{array}{c}\mathrm{Cr} \\
\left(\mathrm{g} / \mathrm{m}^{2} \text {-day }\right)\end{array}$ \\
\hline Brine & 1.0 & 6.3 & 0.0 \\
Silicate & 3.9 & 0.0 & 19.4 \\
De-Ionized Water & 2.0 & 0.0 & 27.8 \\
& & & \\
Note: A zero reading indicates a non-detect in the sample.
\end{tabular}

\subsection{Studies Supporting the Transportation of Calcine to an Offsite Melter}

Several specific tests were performed to examine the maximum waste loading that could be considered as candidate waste form for transportation from INEEL to an offsite melter. Specific tests included compressive strength, 10-m drop test, a DOT oxidizer test, and a minimum melting temperature test.

\subsubsection{Determination of Maximum Waste Loading-Compressive Strength Test}

A mixing study was performed to determine a candidate waste loading to pass a drop test with maximum mass retention, DOT oxidizer testing, and

The mechanical integrity of the waste and its ability to withstand loading pressures in a disposal environment is directly related to compressive strength. Table 9 shows the results of the compressive strength using two different base formulations. Compressive strength for both the base formulations at $80 \%$ waste load is much greater than the minimum Nuclear Regulatory Commission (NRC) requirement of 50 psi. Neither specimen failed under the maximum load available with the selected apparatus, corresponding to greater than 640 psi with 2" diameter samples.

Table 9. Compressive strength for base formulations.

\begin{tabular}{ccc}
\hline Material & $\begin{array}{c}\text { Waste Loading } \\
(\mathrm{wt} \%)\end{array}$ & $\begin{array}{c}\text { Compressive Strength } \\
(\mathrm{psi})\end{array}$ \\
\hline PET 99-1 & $80 \%$ & $>640$ \\
PET 99-2 & $80 \%$ & $>640$ \\
\hline
\end{tabular}

\subsubsection{Drop Test}

The objective of this test was to examine encapsulated sample behavior when dropped from a vertical distance of 10 m onto a stainless steel or concrete surface. For this test, a $80 \%$ sample (PET 99-2 with 5\% JCC2) weighing $215 \mathrm{~g}$ was dropped from a distance of $10 \mathrm{~m}$ (test performed on both a concrete and stainless steel surface). Figure 1 shows the sample before and after the drop test, indicating no 


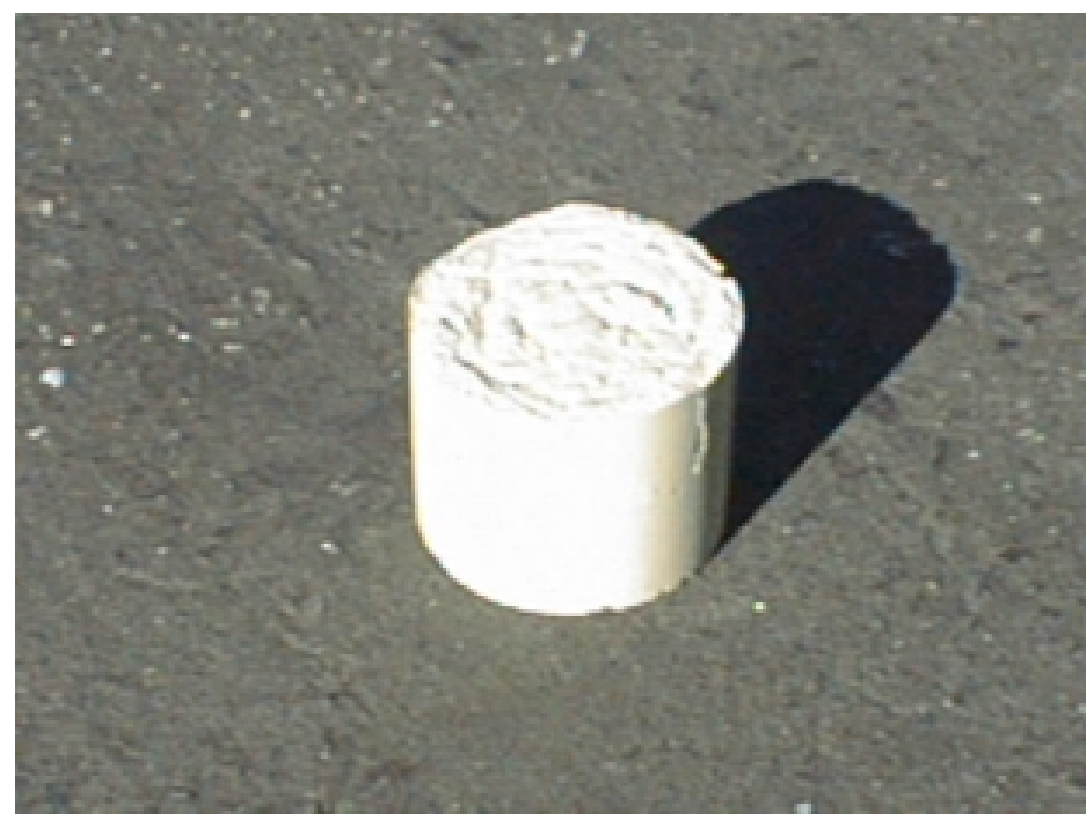

Before Drop Test - PET 99-2, Calcine Waste at 80\% Waste Loading

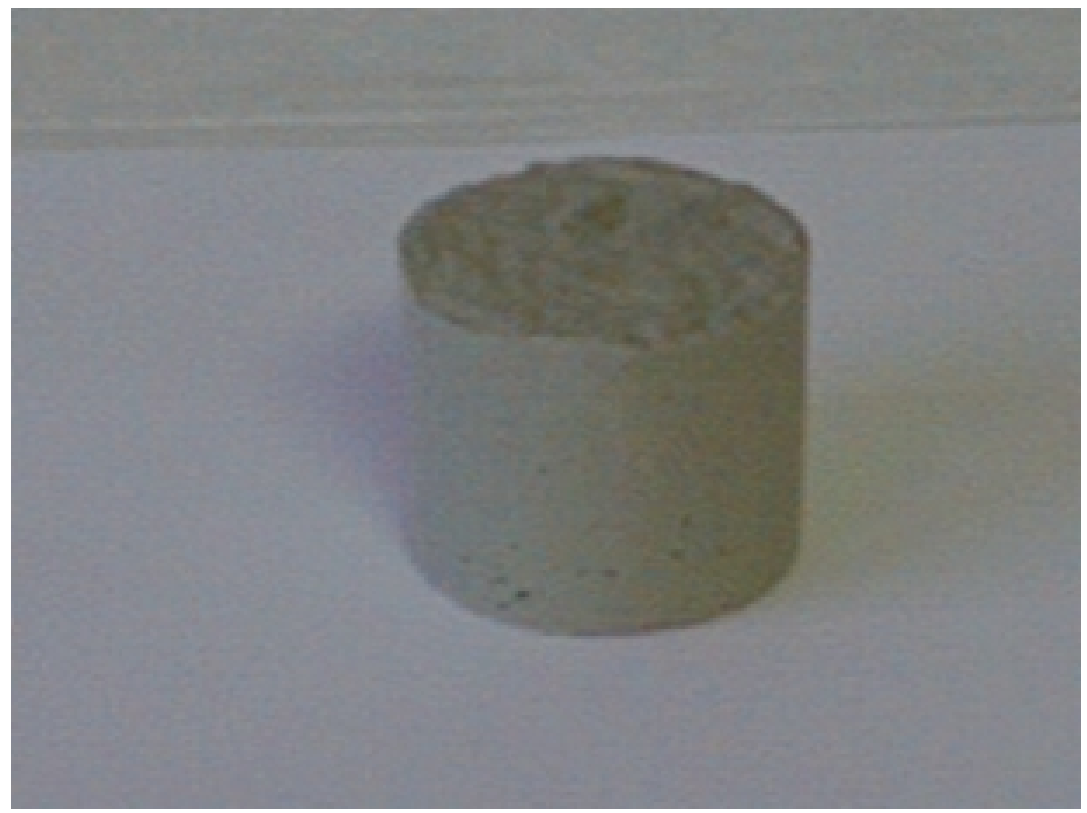

After Drop Test - PET 99-2 Calcine Waste at 80\% Waste Loading

Figure 1. PET 99-2 sample at $80 \%$ waste load (before and after).

fracture and no degradation of the material or its original form. In addition, no debris from the sample was observed on the capture cloth. A video of this drop test is available from Guy Loomis at (208) 5269208 or Jim Giansiracusa at (760)-918-9168. 


\subsubsection{DOT Oxidizer Test}

The basis of this test is to compare a test substance and three reference substances with regards to their ability to increase the burning rate or burning intensity of a combustible solid. Testing was carried out by Hark Laboratories, Inc. (Barberton, Ohio). Each mixture was arranged in a conical pile and a wire loop placed inside the pile. The wire was then heated to $1000^{\circ} \mathrm{C}$ until the first sign of combustion or until it was clear that the mixture would not ignite. The time for combustion was then recorded for each substance. At $80 \%$ waste loading the PET 99-2 material did not burn after approximately 20 minutes. Based on these results the PET 99-2 waste form would not have a specific packing requirement as an oxidizer (i.e., it did not burn).

\subsubsection{Melting Test - Thermal Gravimetric Analysis (TGA)}

Thermal gravimetric analysis was carried out to determine the volatility and melting temperatures of various components of the encapsulated waste sample. Figure 2 shows sample weight loss as a function of temperature using the PET 99-2 formulation at $80 \%$ waste load. There was approximately $5 \%$ weight loss up to $450^{\circ} \mathrm{C}$ and ultimately $11 \%$ weight loss at $1000^{\circ} \mathrm{C}$. Figure 3 shows the sample before and after being exposed to $1000^{\circ} \mathrm{C}$. The remaining residue (a dry powder-like material) is likely silica and other inorganic filler materials, as well as the calcine waste.

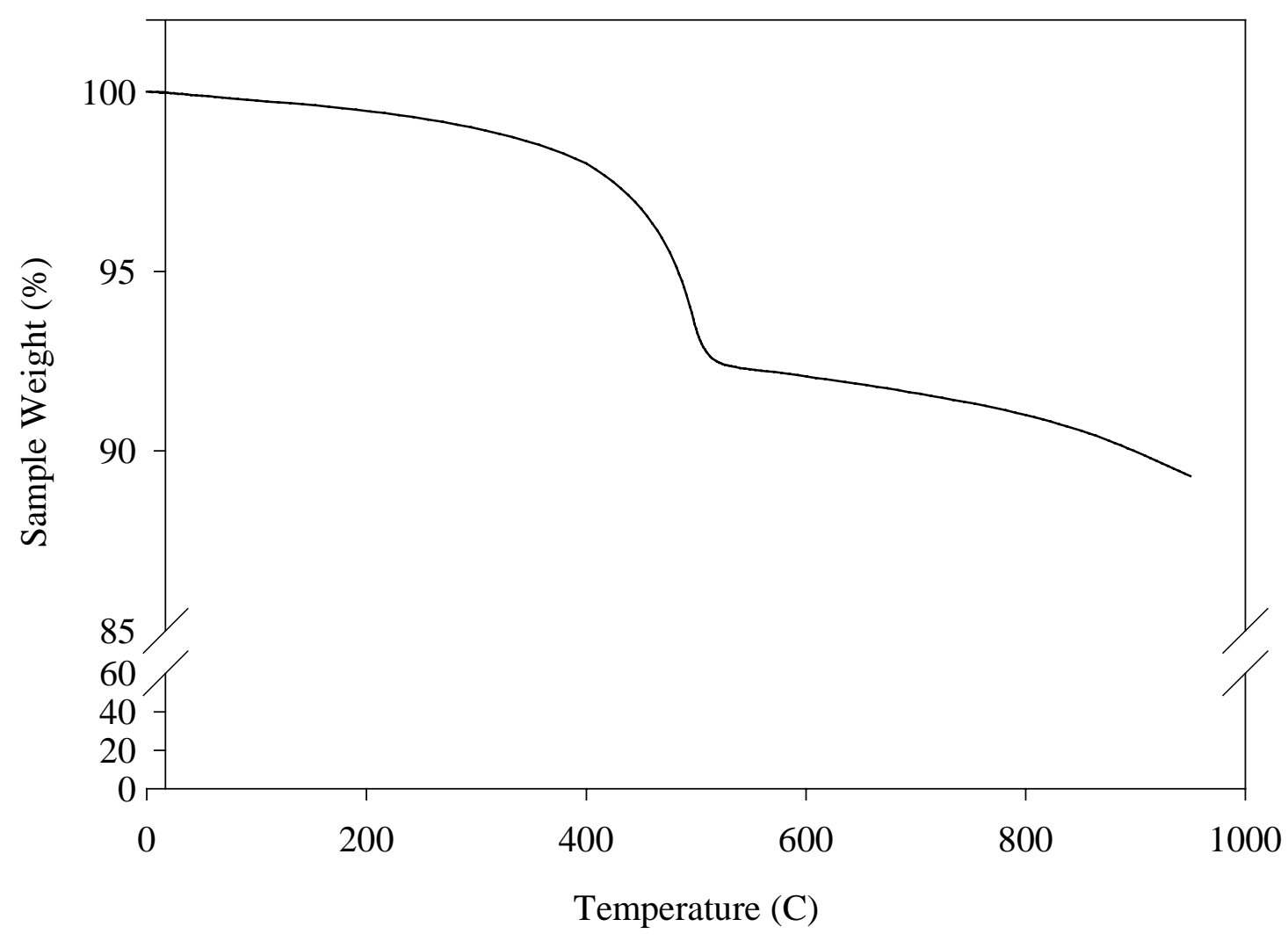

Figure 2. Thermal gravimetric analysis (TGA) of $80 \%$ waste load PET 99-2 sample. 


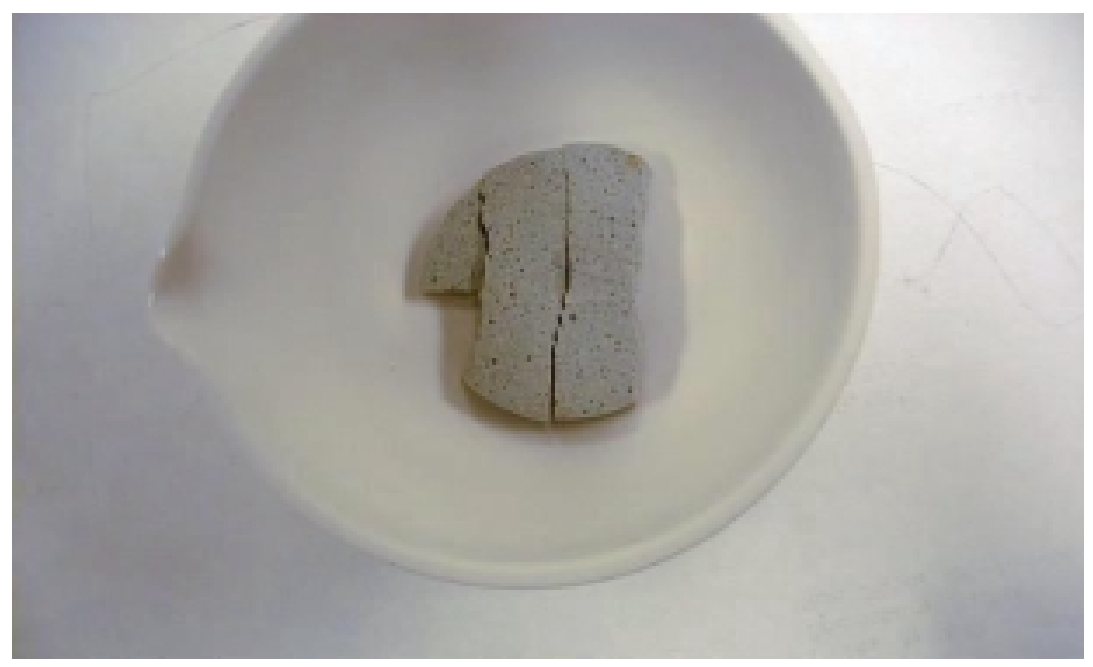

(a)

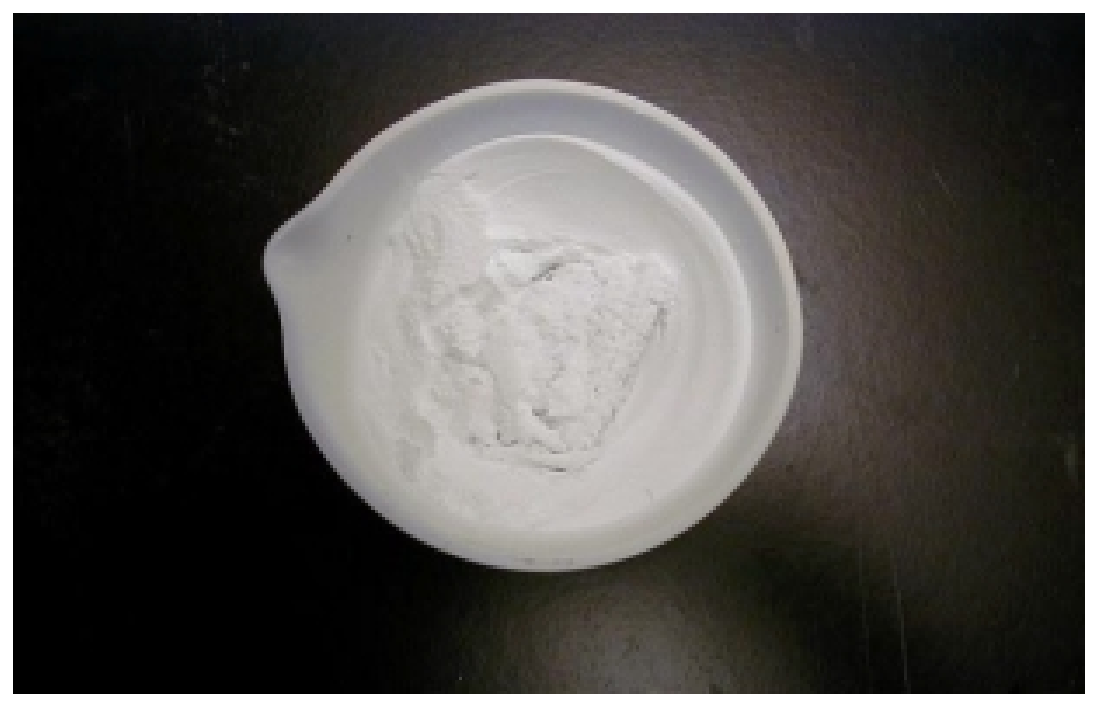

(b)

Figure 3. PET $99-2$ sample at $80 \%$ waste load (a) before and (b) after TGA test $\left(1000^{\circ} \mathrm{C}\right)$. 


\section{DISCUSSION OF RESULTS}

The experimental study showed a positive proof of concept for both applications of the PET process.

Disposal Option: A mixture of $40 \mathrm{wt} \%$ pilot calcine waste with Orbit Technologies PET-99-1 (including proprietary heavy metal scavenger "JJ2") resulted in a waste form that could be considered possible for disposal. With this waste form, Toxicity Characteristic Leaching Procedure (TCLP) testing the Universal Treatment Standard was met for both cadmium and chromium. Further evidence of a positive proof-of concept is that the MCC-1P test on this waste form at $40 \mathrm{wt} \%$ loading showed relatively low concentrations of contaminants in the leachate. The TMLR for all three leachants was less than four $\mathrm{g} / \mathrm{m} 2$-day, with normalized elemental loss rates varying from 0 to $27.8 \mathrm{~g} / \mathrm{m} 2$-day. Leachant characteristic impacts the leaching rate and is metal specific. These numbers compare to values for glass in the "less than $1 \mathrm{~g} / \mathrm{m} 2$-day. Additional evaluation of the leaching rate under variable environmental conditions would be needed to adequately characterize these effects. In addition, a parametric study of various waste loadings should be performed to determine the relationship between waste loading and MCC-1P leach results. Even though these initial results do not meet those found in the glass waste form, the initial results suggest a relatively rugged waste form most likely technically adequate for disposal.

Transportation Option: The concept of using the PET process to encapsulate Calcine waste prior to shipment to an offsite melter has shown a positive proof-of-concept. A cohesive monolith suitable for drop testing was formulated at $80 \mathrm{wt} \%$ pilot calcine material with the PET-99-2 formulation provided by Orbit. The compressive strength of this waste form was above $640 \mathrm{psi}$ and the sample did not burn for 20 minutes in a DOT Oxidizer test. Most importantly, during the drop test on both a concrete floor and steel plate, the monolith was essentially unaffected by the drop, rather it simply elastically bounced. When coupled with an approved stainless steel container virtually no spread of contamination would be expected in a transportation accident. In addition, the material was found to melt at $1000^{\circ} \mathrm{C}$ to a dry "powder like" material meaning it could be reduced to molten form at an offsite melter without chemical dissolution. 


\section{CONCLUSIONS}

1. The concept of using Orbit's PET to encapsulate calcine waste for disposal at a permanent High-Level waste repository has shown a positive proof of concept. Orbit's Polymer Encapsulation Technology created a sample of the encapsulated calcine waste at $40 \%$ loading that passed Universal Treatment Standards for the TCLP testing protocol for the main contaminants of cadmium and chromium present in the pilot calcine material from INEEL. In addition, studies in Russia suggest that the material can withstand high gamma and alpha irradiation without harm. Finally, the first ever test of a PET waste form based on a $40 \mathrm{wt} \%$ pilot calcine showed potential for high durability in the MCC-1P testing.

2. A positive proof-of-concept was obtained for using Orbit's PET for creating a waste form suitable for transportation to an off-site melter. Orbit's Polymer Encapsulation Technology created a sample of the encapsulated calcine waste at $80 \%$ loading that produced a monolith that exceeded 640psi compressive strength. This monolith was dropped $10 \mathrm{~m}$ onto a concrete pad and metal plate without mass loss indicating essentially no contamination spread would be expected in a transportation accident. The monolith also passed the Department of Transportation (DOT) Oxidizer Test and could be melted at $1000^{\circ} \mathrm{C}$ 


\section{RECOMMENDATIONS}

It is recommended that more complete testing and evaluation be conducted of Orbit's PET involving:

1. Pilot scale demonstration with an extruder to determine engineering process parameters for this technology (including drop and flame tests on actual shipping containers possibly simple DOT-7A drums.

2. Optimization and mixing studies to investigate improving the leach rate of contaminants during MCC-1P testing.

3. Evaluating compatibility of the PET waste form with an off-site melter.

4. Cost-benefit analysis to evaluate the efficacy of the disposal and transportation applications of the PET to high-level calcine waste and as a comparison to other base or candidate technologies.

5. Hydrogen generation from radiolysis.

6. Thermal freeze/thaw test for durability.

7. Examine the proposed design of the Hanford melter system and perform compatibility studies relative to (a) removal requirements of calcine/PET waste form from the shipping canister, (b) effects of organic content on the Hanford melter, and (c) size reduction requirements for placing the waste form into the Hanford melter. 


\section{REFERENCES}

1. K. Shvetsov et al., Determination of the Structural Peculiarities of the Material and Components Distribution, Cerametalic Silicon Foam Rubber Research Programme, Kurchatov Institute, April, 1994.

2. G. G. Loomis, Christopher M. Miller and Stephen V. Prewett, Mixed Waste Salt Encapsulation Using Polysiloxane-Final Report, INEEL/EXT-97-01234, November 1997.

3. G.G. Loomis, Christopher M. Miller and Stephen V. Prewett, "Polysiloxane Encapsulation of Mixed Waste Salt," Proceeding of Waste management "98, Tucson, Arizona, March 1-5, 1998.

4. G. G. Loomis and Christopher M. Miller, Polysiloxane Encapsualtion of the Low-Level Fraction of Calcine Mixed Waste at INTEC, INEEL/EXT-98-01173, November 1998.

5. K. Vinjamuri, Effect of Aluminum and Silicon Reactants and Process Parameters on Glass-Ceramic Waste Form Characteristics for Immobilization of High-Level Fluorinel-Sodium Calcined Waste, WINCO-1133, June 1993. 


\section{Appendix A}

Studying of Influence of Inner Alpha-Radiation and GammaRadiation on CSFR 



\section{Appendix B}

\section{Mixed Waste Salt Encapsulation Using Polysiloxane-Final Report}





\section{Appendix C \\ Polysiloxane Encapsulation of the Low-Level Fraction of Calcined Mixed Waste at INTEC}


